\title{
SDHB Negative
}

National Cancer Institute

\section{Source}

National Cancer Institute. SDHB Negative. NCI Thesaurus. Code C156752.

An indication that SDHB expression or activity has not been detected in a sample. 